\title{
Surgical and oncological outcomes of free dermal fat graft for breast reconstruction after breast-conserving surgery
}

\author{
Fabrizio de Biasio ${ }^{1, A-F}$, Serena Bertozzi ${ }^{2, A-F}$, Ambrogio P. Londero ${ }^{3, A-F}$, Daria Almesberger ${ }^{1, A-F}$, \\ Chiara Zanin ${ }^{1, A-F}$, Andrea Marchesii, ${ }^{4, D-F}$, Carla Cedolinii ${ }^{2, A-F}$, Andrea Risaliti ${ }^{2, D-F}$, Pier C. Parodi ${ }^{1, A-F}$ \\ ${ }^{1}$ Clinic of Plastic and Reconstructive Surgery, Department of Medical Area, University of Udine, Italy \\ ${ }^{2}$ Clinic of Surgery, Department of Medical Area, University of Udine, Italy \\ ${ }^{3}$ Clinic of Obstetrics and Gynecology, University of Udine, Italy \\ ${ }^{4}$ Department of Plastic and Reconstructive Surgery, IRCCS Policlinico San Donato, University of Milan, Italy \\ A - research concept and design; $\mathrm{B}$ - collection and/or assembly of data; $\mathrm{C}$ - data analysis and interpretation; \\ $D$ - writing the article; $E$ - critical revision of the article; $F$ - final approval of the article
}

Address for correspondence

Serena Bertozzi

E-mail: dr.bertozzi@gmail.com

Funding sources

None declared

Conflict of interest

None declared

Acknowledgements

We are grateful to Dunya Bernardon

for her suggestions on style and composition

of our text in English.

Received on June 16, 2016

Reviewed on September 26, 2016

Accepted on February 14, 2017

DOI

10.17219/acem/68977

Copyright

Copyright by Author(s)

This is an article distributed under the terms of the

Creative Commons Attribution Non-Commercial License

(http://creativecommons.org/licenses/by-nc-nd/4.0/)

\section{Abstract}

Background. Oncoplastic breast surgery originated in order to improve the esthetic result of breast-conserving surgery (BCS). Autologous free dermal fat graft (FDFG) is an emerging oncoplastic technique to improve the cosmetic outcome of breast-conserving surgery.

Objectives. The aim of this study was to analyze our experience with FDFGs in breast reconstruction after breast-conserving surgery. Oncological outcomes, surgical complications and cosmetic results were considered.

Material and methods. This retrospective chart review study considered all consecutive oncoplastic breast treatment by means of FDFG reconstruction during the period between September 2011 and September 2012 in our Clinic of Surgery (University of Udine, Italy). The data collected included patient and tumor characteristics and outcomes (cosmetic and oncological).

Results. During the study period, 37 women were treated by breast cancer surgery and immediate breast reconstruction by FDFG. Ata 3-year follow-up, we found no cases of recurrence among breast cancer patients treated by FDFG; at a 18-month follow-up, we found a prevalence of $75.0 \%$ of women extremely satisfied with their oncoplastic surgery and a high prevalence of excellent or good cosmetic outcomes (70.3\%) according to objective and subjective cosmetic assessment.

Conclusions. Immediate breast reconstruction by FDFG after BCS in a population selected for a low risk of breast cancer recurrence seems to be an oncologically safe option, with a good cosmetic outcome and a high prevalence of women satisfied with the treatment.

Key words: breast cancer, disease-free survival, free dermal fat graft, oncoplastic surgery, breast-conserving surgery 


\section{Introduction}

During the past 2 decades, breast cancer surgery underwent an important evolution through the introduction of a new concept of oncoplastic breast surgery, which integrates the principles of oncological demolition and plastic reconstruction. ${ }^{1,2}$ Oncoplastic breast surgery initially originated in order to improve the esthetic result of breastconserving surgery (BCS), the indications of which have grown significantly in recent years, ranging from small, wide excisions limited to $10-15 \%$ of the breast to partial mastectomies. ${ }^{1}$ In particular, the dissatisfaction rate after BCS has been reported to be actually $30-40 \%{ }^{3}$

Oncoplastic breast surgery techniques have been classified into 2 main categories: one consists of the residual breast tissue mobilization, and the other requires distant tissue transplantation within the residual breast. ${ }^{4}$ The first category includes all glandular and dermo-glandular flaps described in recent years as well as techniques based on resection patterns typical of reducing mastoplasty. ${ }^{4}$ On the other hand, the latter category consists of the myocutaneous flaps of the latissimus dorsi in its all possible variants, the perforant adipo-fascial flaps of the chest wall and the free flaps of the abdominal region. ${ }^{4,5}$

The optimal choice regarding the best oncoplastic solution depends on the proportion between the resected tissue volume and the whole breast volume as well as on the breast lesion site. Tissue mobilization techniques are generally preferred, because they are easier and quicker to carry out, and, furthermore, do not increase morbidity in different donation sites. However, there are some peremptory indications for tissue transplantation techniques, i.e., when the remaining tissue after breast demolition is insufficient for reconstructing a breast of adequate shape and volume. Unfortunately, choices related to the reconstruction may also be affected by the surgeon's experience, as the learning curve for the flap surgery - and especially microsurgery - often proves to be particularly long; thus, sometimes BCS is turned into mastectomy in order to simplify the surgical procedure.

Among various tissue transplantation techniques, a very important role is played by the free dermal fat graft (FDFG), which is a simple, traditional technique for breast reconstruction. In 2007, Kijima et al. described their experience with this procedure especially for the reconstruction of upper-inner quadrantectomies and in the case of patients who did not qualify for postoperative radiotherapy. ${ }^{5,6}$

Our study aims to analyze our experience with FDFG in breast reconstruction after BCS. In particular, we assessed the surgical outcomes in terms of morbidity and esthetic results, along with the oncological outcomes in terms of overall survival and disease-free survival.

\section{Material and methods}

We collected retrospective data on all patients who underwent reconstructive procedures after BCS for invasive breast cancer between September 2011 and September 2012 in our Clinic of Surgery (University of Udine, Italy). This study follows the dictates of the general authorization law on processing personal data for scientific research purposes on behalf of the Italian Data Protection Authority.

All patients underwent preoperative mammography, breast ultrasound and breast magnetic resonance imaging (MRI) when not contraindicated (e.g., obese women, patients with important comorbidities or those with metallic implants) in order to better define the cancer size and to exclude its eventual multifocality or multicentricity. ${ }^{7}$

About 10 days before surgery, all women were visited by both the breast surgeon and the plastic surgeon in order to plan the incision site and extension as well as the breast site and excision volume, and to discuss the best reconstructive option. All patients gave their informed consent to both demolitive and reconstructive operations.

Indications of FDFG include all breast tissue defects following breast oncological surgery that are located in an area where the graft can rest on the pectoral muscle, and in which the simple dermal and parenchymal remodeling (local tissue mobilization techniques) alone does not yield a satisfactory esthetic result.

The day before surgery, patients with non-palpable lesions underwent the imaging-guided placement of a wire hook together with a radiotracer injection for the sentinel lymph node biopsy as previously described, and were instructed to guide the breast surgeon's excision. ${ }^{8}$ The site of graft sampling was chosen together with the patient based on the potential presence of scars (e.g., cesarean section scar) and the clothing preferences.

All patients underwent general anesthesia and the sentinel lymph node biopsy was performed before breast surgery in order to have the lymph node intraoperatively analyzed. ${ }^{8}$ The incision site for the sentinel lymph node biopsy coincided with the site for breast resection only in the case of upper-outer quadrant lesions. Breast-conserving surgery consisted of the excision of the lesion with adequate margins, including both the skin over the breast lesion and the muscle fascia under it. The specimen was measured and weighed in order to be intraoperatively analyzed later (in order to control the margin negativity). Additionally, in each case, a cavity shave margin excision of about $1 \mathrm{~cm}$ was carried out.

Based on the specimen size and weight, the FDFG site was drawn on the inferior abdominal wall (Fig. 1). Unlike the traditional Kijiama technique - in which the surgeon excises abundant sovrapubic tissue to then design it on the breast defect site, consequently wasting some tissue - we excised a tissue lozenge with a major and a minor diameter and cut it into 2 parts to duplicate its minor diameter. 

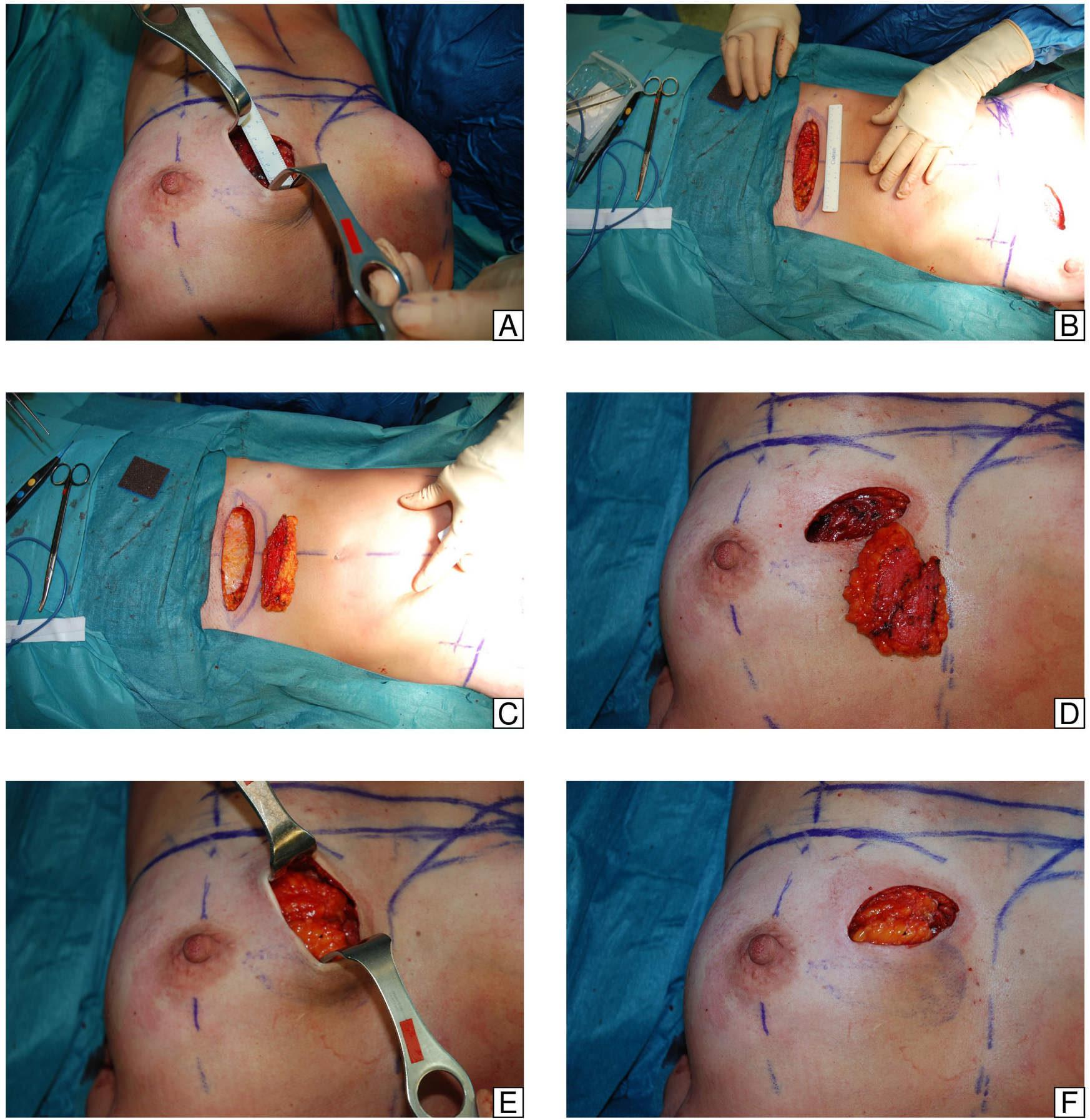

Fig. 1. Surgical procedure

After measuring the size of breast tissue to be replaced after breast cancer excision (A), the plastic surgeon draws the abdominal area of the FDFG site (B), from where he takes the dermo-hypodermic graft (C). Thereafter, the abdominal wall graft is placed and sutured into the breast tissue target area (D-F).

In accordance with Kijiama, we observed that the graft size is well maintained even after the passage of time; thus, it is not required to over-size it.

Sovrapubic tissue was then transferred to any breast defects on an adequate receiving bed, that is to say, on the pectoralis muscle. In particular, the sovrapubic area was initially shaved and then accurately conserved by means of derma vascularization, which is very important for its consequent engraftment. After that, the graft was excised by means of a cold scalpel with a maximum thickness of $2.5 \mathrm{~cm}$, cut and sutured as previously described, then weighed, and finally transferred to the receiving breast area. The graft dermal side was sutured to the pectoralis muscle surface using separate stitches of Vycril 3/0 (Ethicon, Somerville, USA) (Fig. 1).

Before the closure of the wound, drainage was placed in the site of the FDFG, which was maintained in aspiration modality for about 24-48 h. Medication of the donor and the receiving areas was performed with a mild compression and plate dressing, respectively. 
All patients underwent postoperative external breast radiotherapy, and even adjuvant chemotherapy or hormonal therapy were administered when required. Patient follow-up included a yearly oncological examination in order to exclude possible local or distant recurrences, together with a semi-annual check-up until 18 months after surgery for the evaluation of the esthetic results, as some authors described this time interval as the best time to assess definite esthetic outcomes, also including any possible late effects of radiotherapy. ${ }^{9}$

In particular, cosmetic assessment was performed using a score introduced by Sawai et al. and accepted by the Japanese Breast Cancer Society, calculated by summing up the following parameters: breast size (2 - no visual difference, 1 - a slight difference, 0 - a significant difference); breast shape ( 2 - no visual difference, 1 - a slight difference, 0 - a significant difference); scars (2 - unapparent, 1 - apparent, 0 - significantly apparent); breast softness ( 2 - equivalent and soft, 1 - slightly firm or partially firm, 0 - quite firm); size and shape of the nipple-areola complex ( 1 - no difference, 0 - some difference); color of the nipple-areola complex ( 1 - no difference, 0 - some difference); level of the nipple - the difference in the distance from the suprasternal notch between the bilateral nipples $(1-<2 \mathrm{~cm}, 0->2 \mathrm{~cm})$; and the lowest point of the breast - the difference between the bilateral breasts ( 1 - a difference of $<2 \mathrm{~cm}, 0-$ a difference of $>2 \mathrm{~cm}$ ). ${ }^{5,10}$ Total scores of 12 were considered to be excellent, 9-11 were considered good, 5-8 fair, and 0-4 poor. Furthermore, the patients were also asked to give their satisfaction rate according to a 4-point scale (excellent, good, fair, or poor).

The data collected included the following patients characteristics: age and body mass index (BMI) at the time of diagnosis, family history of breast cancer, menopause, and the use of hormonal oral contraceptives. ${ }^{8,11,12}$ Among tumor characteristics, we considered the following: histological type, tumor-nodes-metastasis (TNM) classification and stage, possible extra-axillary lymph node involvement (internal mammary chain and subclavear), nuclear grading, Mib-1/Ki-67 proliferation index, estrogen and progesterone receptor expression, Her2/neu status, and molecular subtypes. ${ }^{8,11,12}$ We also took into consideration other microscopic and histological characteristics which are present in more recent classifications put forward by Arnone et al., and which include the following: multifocality/multicentricity, extensive intraductal component, perivascular invasion, peritumoral inflammation, lymph node extracapsular invasion, and the bunching of the lymph nodes together. ${ }^{8,11-13}$ Regarding surgery, we took into account operative and hospitalization time as well as potential surgical morbidity (defined as surgical site complications happening within 30 days after surgery).

The data was analyzed by $\mathrm{R}$ (v. 3.1.2), with $\mathrm{p}<0.05$ considered significant. The data is presented as proportions (and absolute values), mean ( \pm SD; standard deviation), median (and interquartile range), or percentage of disease-free survival with the relative $95 \%$ confidence interval (CI), where appropriate. Furthermore, survival analysis was performed in order to compare the patients treated with FDFG to our general breast cancer population treated during the same period.

\section{Results}

During the study period, 230 women were treated by means of breast cancer surgery and 125 by BCS. In 37 women, an immediate oncoplastic breast reconstruction by FDFG was carried out.

The mean age of women treated by FDFG was 39.84 years $( \pm 10.25)$ and the mean BMI was $25.85 \mathrm{~kg} / \mathrm{m}^{2}( \pm 5.80)$ (Table 1). The mean follow-up was 33.76 months $( \pm 4.43)$. In 11 women (29.7\%), co-morbidities (3 with hyperthyroidism, 6 with hypertension and 3 with hypercholesterolemia) were present. In total, $13.5 \%$ of these women presented a family history of cancer.

The majority of the treated cancers were ductal invasive cancers, luminal A subtype with a low TNM stage that was mainly 0 or I (Tables 2,3 ). The mean weight of the excised breast tissue was $49.49 \mathrm{~g}( \pm 30.13)$ and the mean surgical time was $38.92 \mathrm{~min}( \pm 5.02)$ (Table 4). Complications developed in 6 cases (16.2\%): 1 case of FDFG necrosis after intraoperative radiotherapy requiring reintervention, 1 hematoma requiring reintervention, 3 seromas, and 1 wound separation managed by outpatient facilities.

Table 1. Description of the population

\begin{tabular}{|c|c|}
\hline Age [years] & $39.84( \pm 10.25)$ \\
\hline $\mathrm{BMI}\left[\mathrm{kg} / \mathrm{m}^{2}\right]$ & $25.85( \pm 5.8)$ \\
\hline Follow-up [months] & $17.76( \pm 4.43)$ \\
\hline Comorbidities & $29.7 \%(11 / 37)$ \\
\hline Tobacco smoke & $24.3 \%(9 / 37)$ \\
\hline Family history of cancer & $13.5 \%(5 / 37)$ \\
\hline Previous use of estrogens & $2.7 \%(1 / 37)$ \\
\hline Post-menopausal status & $56.8 \%(21 / 37)$ \\
\hline $\begin{array}{l}1^{\text {st }} \text { breast surgical intervention } \\
\text { BCS } \\
\text { NSM }\end{array}$ & $\begin{array}{c}94.6 \%(35 / 37) \\
5.4 \%(2 / 37)\end{array}$ \\
\hline $\begin{array}{l}2^{\text {nd }} \text { breast surgical intervention } \\
\text { nothing } \\
\text { margin widening } \\
\text { SSM }\end{array}$ & $\begin{array}{c}82.9 \%(29 / 35) \\
14.3 \%(5 / 35) \\
2.9 \%(1 / 35)\end{array}$ \\
\hline $\begin{array}{l}\text { Definitive axilla surgery } \\
\text { SLNB } \\
\text { CALND }\end{array}$ & $\begin{array}{c}89.2 \%(33 / 37) \\
10.8 \%(4 / 37)\end{array}$ \\
\hline $\begin{array}{l}\text { Non-surgical treatments } \\
\text { neoadjuvant chemotherapy } \\
\text { adjuvant radiotherapy } \\
\text { adjuvant chemotherapy } \\
\text { adjuvant hormonal therapy }\end{array}$ & $\begin{array}{c}0 \%(0 / 37) \\
86.5 \%(32 / 37) \\
35.1 \%(13 / 37) \\
75.7 \%(28 / 37)\end{array}$ \\
\hline
\end{tabular}

$\mathrm{BMI}$ - body mass index; BCS - breast-conserving surgery; NSM - nipple sparing mastectomy; SSM - skin sparing mastectomy; SLNB - sentinel lymph node biopsy; CALDN - complete axilla lymph node dissection. 
Table 2. Tumor characteristics

\begin{tabular}{|c|c|}
\hline $\begin{array}{l}\text { Histological type } \\
\text { ductal invasive carcinoma } \\
\text { lobular invasive carcinoma } \\
\text { ductal and lobular invasive carcinoma } \\
\text { other invasive carcinoma } \\
\text { ductal in situ carcinoma }\end{array}$ & $\begin{array}{c}67.6 \%(25 / 37) \\
5.4 \%(2 / 37) \\
8.1 \%(3 / 37) \\
8.1 \%(3 / 37) \\
10.8 \%(4 / 37)\end{array}$ \\
\hline $\begin{array}{l}\text { Tumor characteristics } \\
\text { Mib-1 > 20\% } \\
\text { comedo-like necrosis } \\
\text { multifocality/multicentricity } \\
\text { EIC } \\
\text { PVI }\end{array}$ & $\begin{array}{c}29 \%(9 / 31) \\
13.5 \%(5 / 37) \\
8.1 \%(3 / 37) \\
16.2 \%(6 / 37) \\
18.9 \%(7 / 37)\end{array}$ \\
\hline $\begin{array}{l}\text { Molecular subtype } \\
\text { luminal A } \\
\text { luminal B } \\
\text { basal-like } \\
\text { luminal Her } \\
\text { Her enriched }\end{array}$ & $\begin{array}{c}59.4 \%(22 / 37) \\
27 \%(10 / 37) \\
8.1 \%(3 / 37) \\
2.7 \%(1 / 37) \\
2.7 \%(1 / 37)\end{array}$ \\
\hline $\begin{array}{l}\text { Lymph node characteristics } \\
\text { non axilla locoregional lymph node } \\
\text { metastasis } \\
\text { ITC } \\
\text { micrometastasis } \\
\text { extracapsular lymph node invasion } \\
\text { axilla lymph node bunching }\end{array}$ & $\begin{array}{c}0 \%(0 / 37) \\
2.7 \%(1 / 37) \\
0 \%(0 / 37) \\
2.7 \%(1 / 37) \\
0 \%(0 / 37)\end{array}$ \\
\hline \multicolumn{2}{|c|}{$\begin{array}{l}\text { EIC - extended intraductal component; PVI - peritumoral vascular } \\
\text { invasion; ITC - isolated tumor cells. }\end{array}$} \\
\hline $\begin{array}{l}\text { Tumor size } \\
\text { Tis } \\
\text { T1 } \\
\text { T2 }\end{array}$ & $\begin{array}{c}10.8 \%(4 / 37) \\
83.8 \%(31 / 37) \\
5.4 \%(2 / 37)\end{array}$ \\
\hline $\begin{array}{l}\text { Nodal status } \\
\text { N0 } \\
\text { N1 } \\
\text { N2 }\end{array}$ & $\begin{array}{c}89.2 \%(33 / 37) \\
8.1 \%(3 / 37) \\
2.7 \%(1 / 37)\end{array}$ \\
\hline $\begin{array}{l}\text { TNM stage } \\
\text { stage } 0 \\
\text { stage I } \\
\text { stage II }\end{array}$ & $\begin{array}{c}10.8 \%(4 / 37) \\
75.7 \%(28 / 37) \\
13.5 \%(5 / 37)\end{array}$ \\
\hline $\begin{array}{l}\text { Tumor grading } \\
\text { G } 1 \\
\text { G } 2 \\
\text { G } 3\end{array}$ & $\begin{array}{l}22.9 \%(8 / 35) \\
42.9 \%(15 / 35) \\
34.3 \%(12 / 35)\end{array}$ \\
\hline
\end{tabular}

Margin involvement was found in 1 case (2.7\%) after definitive histological examination - it required another surgery for margin widening. In 1 case, a skin sparing mastectomy was required because of multicentricity/multifocality found after definitive histological examination.

In the study group, 75\% (27/36) of women declared an excellent esthetic result at a 18-month follow-up, the other $25.0 \%$ (9/36) declared a good or fair esthetic result, and none declared a poor result. Furthermore, in Table 5 we show the cosmetic assessment according to the Sawai score at a 18-month follow-up; the majority of cases presented an excellent or good total score (Table 5, Fig. 2).

During the follow-up, among the 37 cases treated by means of FDFG, we found no cases of local or distant recurrence. During the same period, in the cases treated by BCS, we registered a disease-free survival at a 3-year follow-up of $95.1 \%$
Table 4. Characteristics of reconstructive surgery

\begin{tabular}{|l|c|}
\hline Weight of excised breast tissue $[\mathrm{g}]$ & $49.49( \pm 30.33)$ \\
\hline Surgical time $[\mathrm{min}]$ & $38.92( \pm 5.02)$ \\
\hline Hospitalization time [days] & $3.27( \pm 0.61)$ \\
\hline Complications & $16.2 \%(6 / 37)$ \\
\hline Margin involvement & $2.7 \%(1 / 37)$ \\
\hline
\end{tabular}

Table 5. Objective and subjective assessment (Sawai's cosmetic assessment, Japanese Breast Cancer Society)

\begin{tabular}{|c|c|}
\hline $\begin{array}{l}\text { Size of the breast } \\
\text { no visual difference (2) } \\
\text { a slight difference (1) } \\
\text { a significant difference (0) }\end{array}$ & $\begin{array}{c}67.6 \%(25 / 37) \\
24.3 \%(9 / 37) \\
8.1 \%(3 / 37)\end{array}$ \\
\hline $\begin{array}{l}\text { Shape of the breast } \\
\text { no visual difference (2) } \\
\text { a slight difference (1) } \\
\text { a significant difference (0) }\end{array}$ & $\begin{array}{c}70.3 \%(26 / 37) \\
16.2 \%(6 / 37) \\
13.5 \%(5 / 37)\end{array}$ \\
\hline $\begin{array}{l}\text { Scar } \\
\text { unapparent (2) } \\
\text { apparent (1) } \\
\text { significantly apparent (0) }\end{array}$ & $\begin{array}{c}70.3 \%(26 / 37) \\
21.6 \%(8 / 37) \\
8.1 \%(3 / 37)\end{array}$ \\
\hline $\begin{array}{l}\text { Softness of the breast } \\
\text { equivalent and soft (2) } \\
\text { slightly firm or partially firm (1) } \\
\text { quite firm (0) }\end{array}$ & $\begin{array}{c}32.4 \%(12 / 37) \\
56.8 \%(21 / 37) \\
10.8 \%(4 / 37)\end{array}$ \\
\hline $\begin{array}{l}\text { Size and shape of nipple-areola } \\
\text { no difference (1) } \\
\text { some difference (0) }\end{array}$ & $\begin{array}{c}81.1 \%(30 / 37) \\
18.9 \%(7 / 37)\end{array}$ \\
\hline $\begin{array}{l}\text { Color of the nipple-areola } \\
\text { no difference (1) } \\
\text { some difference (0) }\end{array}$ & $\begin{array}{c}86.5 \%(32 / 37) \\
13.5 \%(5 / 37)\end{array}$ \\
\hline $\begin{array}{l}\text { Level of the nipple } \\
\text { a difference of }<2 \mathrm{~cm}(1) \\
\text { a difference of }>2 \mathrm{~cm}(0)\end{array}$ & $\begin{array}{c}89.2 \%(33 / 37) \\
10.8 \%(4 / 37)\end{array}$ \\
\hline $\begin{array}{l}\text { Level of the lowest point of the breast } \\
\text { a difference of }<2 \mathrm{~cm}(1) \\
\text { a difference of }>2 \mathrm{~cm}(0)\end{array}$ & $\begin{array}{c}91.9 \%(34 / 37) \\
8.1 \%(3 / 37)\end{array}$ \\
\hline $\begin{array}{l}\text { Total score (assessment) } \\
\text { excellent (12) } \\
\text { good (9-11) } \\
\text { fair }(5-8) \\
\text { poor }(0-4)\end{array}$ & $\begin{array}{c}9.49( \pm 1.92) \\
5.4 \%(2 / 37) \\
64.9 \%(24 / 37) \\
29.7 \%(11 / 37) \\
0 \%(0 / 37)\end{array}$ \\
\hline
\end{tabular}

(95\% CI 90.9-99.6\%) ( $\mathrm{p}$ - nonsignificant). No case of a cancerrelated death in either group was observed.

\section{Discussion}

At a 3-year follow-up, we found high disease-free survival among breast cancer patients treated with FDFG, and at a 18-month follow-up, we found a high prevalence of women extremely satisfied by oncoplastic surgery and an excellent level of a cosmetic outcome.

Although oncological safety regarding breast surgery surely constitutes the most important aim while treating breast cancer, great attention is always given to the esthetic result, and oncoplastic breast surgery represents the most important progress achieved in the last 2 decades. 

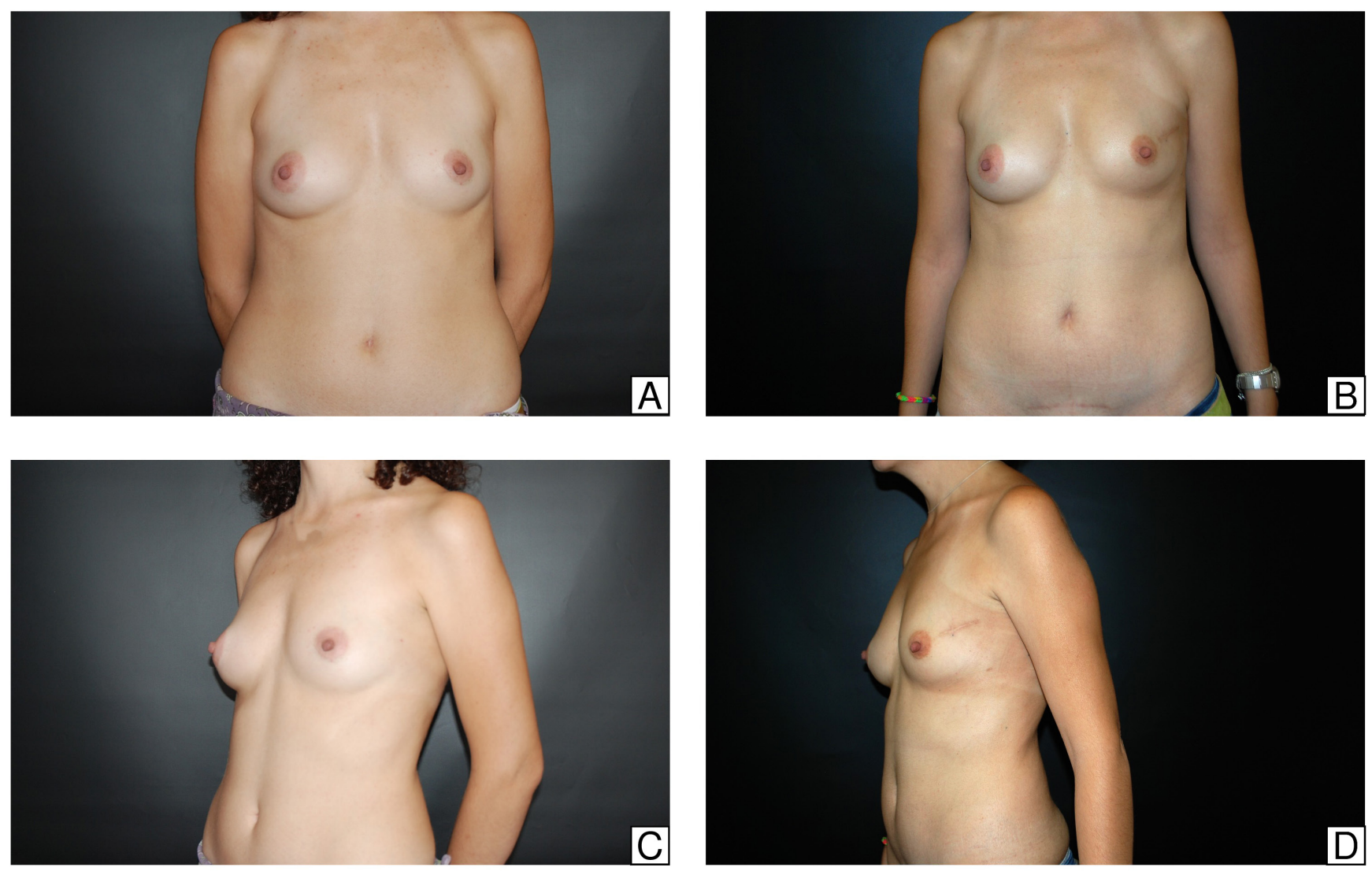

C
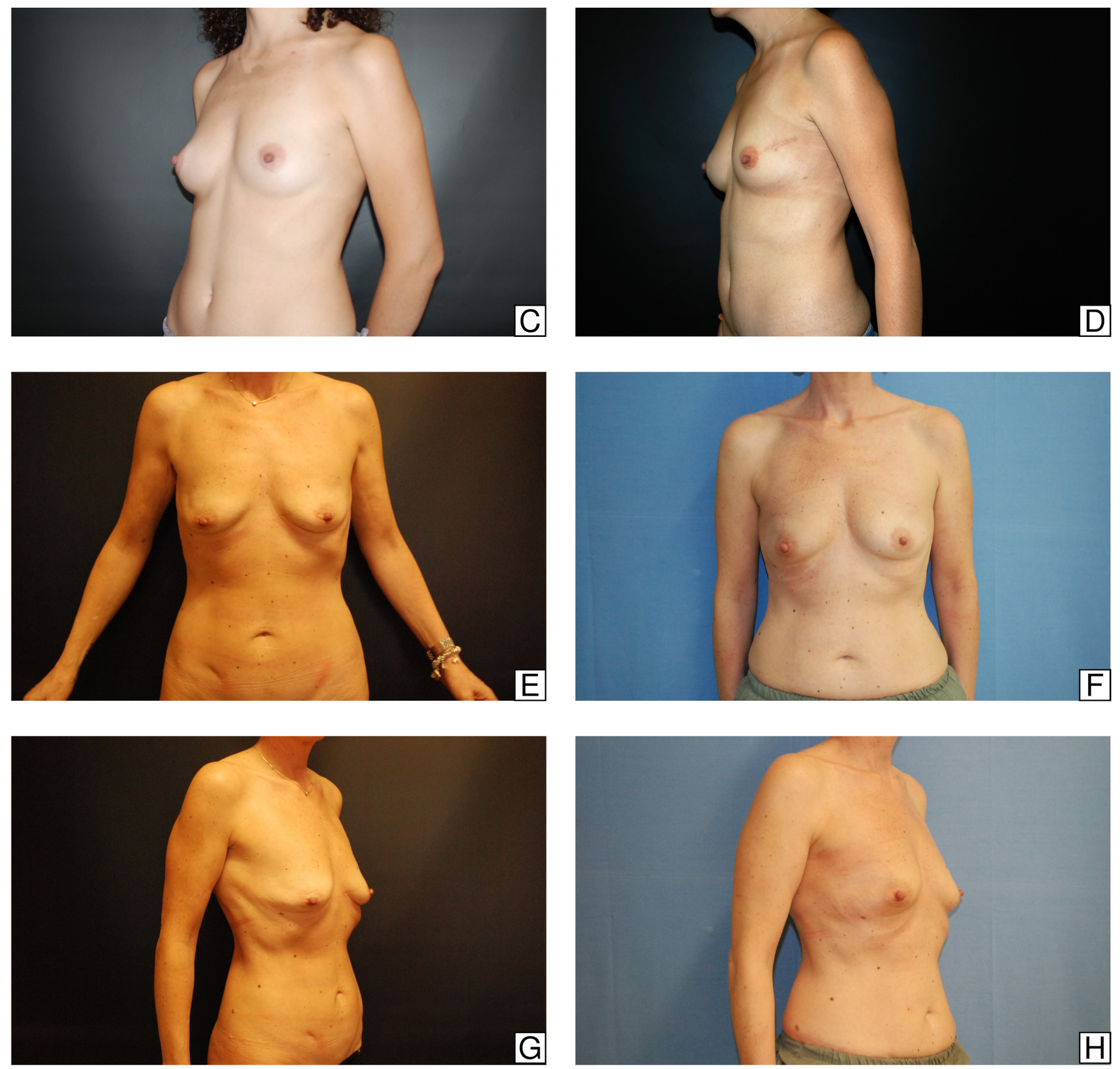

Fig. 2. Cosmetic assessment at a 18-month follow-up

Two cases are shown in the panels. $A$ and $C$ are pre-surgery case $1 ; B$ and $D$ are post-surgery case 1 (surgery site in the left breast upper external quadrant). $\mathrm{E}$ and $\mathrm{G}$ are pre-surgery case 2; $\mathrm{F}$ and $\mathrm{H}$ are post-surgery case 2 (surgery site in the right breast upper external quadrant). 
In fact, Clough et al. demonstrated that the introduction of oncoplastic surgical techniques allowed the excision of a 4 times greater tissue volume than in the case of traditional quadrantectomy. ${ }^{14} \mathrm{~A}$ meta-analysis of Haloua et al. revealed that oncoplastic surgical techniques significantly reduced margin positivity rates of BCS from about 20-40\% in the case of traditional quadratectomy to $3-16 \%$ in oncoplastic surgery, and significantly increased esthetic satisfaction rates up to $84-89 \%$. $^{4}$

Despite the great results of oncoplastic surgery described in the recent literature, in our experience some difficulties occurred which must be considered, such as an unfavorable proportion of breast volume to excised tissue volume. In particular, demolition involving less than $20 \%$ of the breast generally allows for adequate reconstruction independently of breast size; in fact, medium- and large-sized breasts may be submitted so as to reduce mastoplasty with good esthetic results, especially for women who desire a reduction in their breast size. On the other hand, demolition involving more than $20 \%$ of the breast in the cases of small-sized breasts may compromise the esthetic result of BCS and lead the surgeon to choose a mastectomy, also due to the long surgical time and the significant morbidity of traditional flap surgery; these women represent the group of patients who would have greater benefits thanks to the introduction of FDFG.

Thanks to the preoperative breast MRI study and the intraoperative resection margin evaluation, the 5-year recurrence rate after BCS in our population was $0 \%$ at a 3 -year follow-up, and $75 \%$ of the women declared an excellent esthetic result. Of the remaining 25\%, the majority were women with an unfavorable proportion between breast volume and excised tissue volume.

An intraoperative margin evaluation, as well as a subsequent systematic cavity shave margin excision, aim to further reduce the margin positivity rate, especially since some authors observed evident difficulty in margin widening after oncoplastic surgery with a consequent increased rate of secondary mastectomies. ${ }^{4}$ Free dermal fat graft allows breast surgeons to excise as much tissue as it is required in a more tranquil manner so as to reach oncological radicality. Furthermore, a graft size which may influence its engraftment is not so much a question of length but of thickness, so in the case of large breast defects, a larger sovrapubic tissue excision is required. In any case, if margin widening is required, it is always possible to perform the $2^{\text {nd }}$ intervention followed by traditional tissue mobilization techniques.

Free dermal fat graft proves to allow very simple and quick execution, and does not require particular skills, so the majority of breast surgeons can perform it.

In the current literature, FDFG has an early and late morbidity of $20 \%$ and $10 \%$, respectively. In our specific cases, we registered a complication prevalence of $16.2 \%$ - mainly minor ones, treated in outpatient facilities. Furthermore, only a single case of graft loss was reported in a woman who underwent intraoperative radiotherapy, which was consequently considered to be an absolute contraindication.

The main limitation of the present study is the short oncological follow-up; however, the use of this kind of procedure is limited and only minor studies with short followup periods have been published. ${ }^{5,15}$ In fact, most of the recurrences in breast cancer occur between the $3^{\text {rd }}$ and the $6^{\text {th }}$ year of follow-up. ${ }^{16}$ However, recent studies analyzing the oncological outcome of autologous fat grafting have declared this procedure to be safe even with a shorter mean follow-up than ours $(<21$ months of follow-up vs 34 months). ${ }^{15,17}$ It must be stressed that in all aspects considered in the current literature, so far nothing has demonstrated the worsening of oncological outcomes as a result of using these techniques. ${ }^{5,15,17-19}$ Finally, there is a cosmetic improvement achieved by using these techniques in oncoplastic surgery, as they allow the reconstruction of defects in areas difficult to repair, such as upper inner quadrants, or in small and medium-sized breasts.

To summarize, FDFG oncoplastic surgery, in a population of breast cancer patients selected for low oncological risk, seems to be oncologically safe, with a good cosmetic outcome and a high level of satisfaction of the women treated.

\section{References}

1. Driul L, Bernardi S, Bertozzi S, Schiavon M, Londero AP, Petri R. New surgical trends in breast cancer treatment: Conservative interventions and oncoplastic breast surgery. Minerva Ginecol. 2013;65:289-296.

2. Urban C, Lima R, Schunemann E, Spautz C, Rabinovich I, Anselmi K. Oncoplastic principles in breast conserving surgery. Breast. 2011; 20(Suppl 3):92-95.

3. Blondeel PN, Hijjawi J, Depypere H, Roche N, Van Landuyt K. Shaping the breast in aesthetic and reconstructive breast surgery: An easy three-step principle. Part III - Reconstruction following breast conservative treatment. Plast Reconstr Surg. 2009;124:28-38.

4. Haloua $\mathrm{MH}$, Krekel NMA, Winters $\mathrm{HAH}$, et al. A systematic review of oncoplastic breast-conserving surgery: Current weaknesses and future prospects. Ann Surg. 2013;257:609-620.

5. Kijima $Y$, Yoshinaka H, Funasako $Y$, et al. Immediate breast reconstruction using autologous free dermal fat grafts provides better cosmetic results for patients with upper inner cancerous lesions. Surg Today. 2011;41:477-489.

6. Kijima Y, Yoshinaka H, Owaki T, Aikou T. Early experience of immediate reconstruction using autologous free dermal fat graft after breast conservational surgery. J Plast Reconstr Aesthet Surg. 2007;60:495-502.

7. Del Frate C, Borghese L, Cedolini C, et al. Role of pre-surgical breast MRI in the management of invasive breast carcinoma. Breast. 2007;16: 469-481.

8. Cedolini C, Bertozzi S, Seriau L, et al. Eight-year experience with the intraoperative frozen section examination of sentinel lymph node biopsy for breast cancer in a North-Italian university center. Int J Clin Exp Pathol. 2014;7:364-371.

9. Vrieling C, Collette L, Fourquet A, et al.; EORTC Radiotherapy and Breast Cancer Cooperative Groups. The influence of patient, tumor and treatment factors on the cosmetic results after breast-conserving therapy in the EORTC 'boost vs no boost' trial. Radiother Oncol. 2000;55:219-232.

10. Ozaki S, Ohara M, Shigematsu H, et al. Technical feasibility and cosmetic advantage of hybrid endoscopy-assisted breast-conserving surgery for breast cancer patients. J Laparoendosc Adv Surg Tech A. 2013;23:91-99.

11. Cedolini C, Bertozzi S, Londero AP, et al. Type of breast cancer diagnosis, screening, and survival. Clin Breast Cancer. 2014;14:235-240. 
12. Cedolini C, Bertozzi S, Seriau L, et al. Feasibility of conservative breast surgery and intraoperative radiation therapy for early breast cancer: A single-center, open, non-randomized, prospective pilot study. Oncol Rep. 2014;31:1539-1546.

13. Arnone $\mathrm{P}$, Zurrida $\mathrm{S}$, Viale $\mathrm{G}$, et al. The TNM classification of breast cancer: Need for change. Updates Surg. 2010;62:75-81.

14. Clough KB, Lewis JS, Couturaud B, Fitoussi A, Nos C, Falcou MC. Oncoplastic techniques allow extensive resections for breast-conserving therapy of breast carcinomas. Ann Surg. 2003;237:26-34.

15. Biazus JV, Falcão CC, Parizotto $\mathrm{AC}$, et al. Immediate reconstruction with autologous fat transfer following breast-conserving surgery. Breast J. 2015; 21(3):268-275.
16. Bernardi S, Bertozzi S, Londero AP, et al. Nine years of experience with the sentinel lymph node biopsy in a single Italian center: A retrospective analysis of 1,050 cases. World J Surg. 2012;36:714-722.

17. Petit JY, Lohsiriwat V, Clough KB, et al. The oncologic outcome and immediate surgical complications of lipofilling in breast cancer patients: A multicenter study - Milan-Paris-Lyon experience of 646 lipofilling procedures. Plast Reconstr Surg. 2011;128:341-346.

18. Semprini G, Cattin F, Lazzaro L, Cedolini C, Parodi PC. About locoregional recurrence risk after lipofilling in breast cancer patients. Ann Oncol. 2012;23:802-804.

19. Semprini G, Cattin F, Zanin C, et al. About locoregional recurrence risk after lipofilling in breast cancer patients: Our experience. Minerva Chir. 2014;69:91-96. 